DOI: $10.17516 / 1997-1370-0763$

УДК 811.51

\title{
The Even Language: Studying, Teaching and Linguistic Ecology Challenges
}

\author{
Alexander A. Petrova,c and Veronica A. Razumovskaya ${ }^{b}$ \\ ${ }^{a}$ Herzen State Pedagogical University of Russia \\ St. Petersburg, Russian Federation \\ ${ }^{b}$ Siberian Federal University \\ Krasnoyarsk, Russian Federation \\ ${ }^{c}$ M.K. Ammosov North-Eastern Federal University \\ Yakutsk, Russian Federation
}

Received 05.03.2021, received in revised form 21.04.2021, accepted 21.05.2021

\begin{abstract}
The article is devoted to the history of the study and teaching of the Even (Lamut) language in Russia in the period from the $17^{\text {th }}-$ to the beginning of the $21^{\text {st }}$ century. Special attention is paid to the problem of linguistic ecology. The fundamental and applied researches in the synchronic and diachronic aspects, as well as issues of teaching the Even language in families, pre-school educational institutions, colleges and higher educational institutions of Russia are studied. Ethnolinguistics is considered as a possible tool of language preservation and development, i. e., the Even language teaching in the close connection with traditional and modern material and spiritual culture. In this way, the role of vocabulary reflecting the song and dance creative activity, decorative and applied art, ceremonies (of life cycle: birth, wedding, funeral) and economy (hunting, fishing, reindeer breeding), taboo and euphemisms, folk knowledge (metrology, meteorology, space orientation, medicine, calendar, food and cuisine, etc.), as well as the words of religious beliefs (animism, shamanism, Christianity) in the formation of a language picture of the world and the Evens' mentality is being determined. The role of state institutions, civil society organizations, as well as the members of small-numbered ethnic groups per se in the preservation and development of their language and culture is described. The attention is paid to the translation as the tool of a unique language preservation.
\end{abstract}

Keywords: the Even (Lamut) language, research, teaching, linguistic ecology, ethnolinguistics, language and culture, language picture of the world, mentality, translation.

Research area: culturology; philology.

Citation: Petrov, A.A., Razumovskaya, V.A. (2021). The Even language: studying, teaching and linguistic ecology challenges. J. Sib. Fed. Univ. Humanit. Soc. Sci., 14(6), 822-833. DOI: 10.17516/1997-1370-0763.

(C) Siberian Federal University. All rights reserved

* Corresponding author E-mail address: petrovalexspb@mail.ru, vrazumovskaya@sfu-kras.ru ORCID: 0000-0003-0075-3742 (Petrov); 0000-0002-0751-7964 (Razumovskaya) 


\title{
Эвенский язык: исследования, преподавание, вызовы лингвоэкологии
}

\author{
A.A. Петров в, в, В.А. Разумовская \\ ароссийский государственный педагогический \\ университет им. А. И. Гериена \\ Российская Федерация, Санкт-Петербург \\ ${ }^{6}$ Сибирский федеральный университет \\ Российская Федерачия, Красноярск \\ ${ }^{6}$ Северо-Восточный федеральный университет \\ имени М. К. Аммосова \\ Российская Федерация, Якутск
}

\begin{abstract}
Аннотация. Статья посвящена истории изучения и преподавания эвенского (ламутского) языка в России в период с XVII- по начало XXI века. Отдельное внимание уделено проблеме лингвоэкологии языка. Рассматриваются фундаментальные и прикладные исследования в синхронном и диахроническом аспектах, а также вопросы преподавания эвенского языка в семье, дошкольных образовательных учреждениях, колледжах и высших учебных заведениях России. Изучаются возможности этнолингвистики для сохранения и развития языка: преподавание эвенского языка в тесной связи с традиционной и современной материальной и духовной культурой. Для этого устанавливается роль лексики, связанной с песеннотанцевальным творчеством, с декоративно-прикладным искусством, обрядовой лексики жизненного цикла (рождение, свадьба, похороны), производственной (охотничьи, рыболовецкие, оленеводческие обряды) лексики; табу и эвфемизмов; лексики, связанной с народными знаниями (метрология, метеорология, ориентация в пространстве, медицина, календарь, питание и кухня и др.), а также слов, отражающих религиозные воззрения (анимизм, шаманизм, христианство) в формировании языковой картины мира и менталитета эвенов. Отмечена роль государственных институтов, общественных организаций, а также самих представителей малочисленного этноса в сохранении и развитии своих языка и культуры. Обращено внимание на перевод как инструмент сохранения уникального языка.
\end{abstract}

Ключевые слова: эвенский (ламутский) язык, исследование, преподавание: лингвоэкология, этнолингвистика, язык и культура, языковая картина мира, менталитет, перевод.

Научные специальности: 24.00.00 - культурология; 10.00.00 - филологические науки.

\section{Introduction}

The Even (Lamut) language belongs to the North (Siberian) group of Tungus-Manchu languages of the Altai linguistic family. The Evens represent a people of Russia, regarded as indigenous minorities of the North, Siberia and the Far East (Rasporyazhenie Pravitel'stva, 2006). In ethnographic studies, the Evens are also called the Lamuts («lamu» in Even means «sea» or «people, who live by the sea»). In accordance with the regional self-naming tradition, they are also known as Evens, Orochi, Ilkany, Mene, Donretkeny, Namatkany. The community still recognizes itself as a part of certain kins, i. e., the Kukuyun, Myamyal', Doida, Dellyankin, Dutki, Dolgan, Uyagan, etc.

The first data about the Evens and their language belong to Russian as well as foreign explorers and scientists of the $17^{\text {th }}-18^{\text {th }}$ centuries: N. K. Witsen, J. Lindenau, S. P. Krashen- 
innikov, P. S. Pallas and others. The records about the Evens were made by G. A. Sarychev, M. M. Robek, F. P. Adelung, J. H. Klaproth, A. Schiefner, A. Middendorff, S. K. Patkanov, A. D. Kiber, arch-priest Stephan Popov and others in the $19^{\text {th }}$ century. The first Even books were published in Moscow: «The Tungus ABC-book with Prayers», «The Concise Tungus Dictionary» (by Stephan Popov, an arch-priest of the Tauisk Intercession Church», published in the Synodic Publishing House, in 1858-1859). Ethnographic, anthropologic and linguistic studies of the Evens were continued in the Soviet era by V. G. Bogoraz, V. I. Levin, V. I. Tsintsius, L. D. Rishes, E. P. Orlova, M. G. Levin, U. G. Popova, K. A. Novikova, N. I. Gladkova, A. B. Spevakovskiy, V.D. Lebedev, V.A. Robbek, Kh. I. Dutkin, Zh. K. Lebedeva, A. A. Burykin, A. L. Mal'chukov, A. A. Petrov, A. A. Alekseev and others. The post-Soviet period and the beginning of the $21^{\text {st }}$ century is marked by the works of V.G. Belolyubskaya, U. P. Tarabukina, R. S. Nikitina, S. I. Sharina, R. P. Kuz'mina, E. B. Nesterova, G. V. Robbek, S. A. Alekseeva, S. N. Savvinova, I. I. Sadovnikova, E. E. Beglova (Balaganchik), M. S. Tolstova (Belolyubskaya), V. S. Fedorenkova (Yermolaeva), M. P. Dyakonova and others.

The Evens occupy the territory of Abyiskiy, Bulunskiy, Kobyaiskiy, Srednekolymskiy, Verkhekolymskiy, Nizhnekolymskiy, Ust'-Yanskiy, Oymyakonskiy, Tomponskiy, Momskiy, Allaikhovskiy, Verkhoyanskiy, Even-Bytantaiskiy districts (uluses) of the Republic of Sakha (Yakutia); the area of the Okhotsk Sea cost and the nearby districts of the Upper-Kolyma basin and the Penzhina and Gizhigin Bays; Okhotsk and Upper-Bureinsk districts of Khabarovsk Krai; Ol'skiy, Severo-Evenskiy, Ten'kinskiy, Khasynskiy, Yagodinskiy and Sredne-Kanskiy districts of Magadan Oblast'; Bystrinskiy, Penzhinskiy, Olyutorskiy and Tigil'skiy districts of Kamchatka Oblast' (after 2007 - Kamchatka Krai); Bilibinskiy, Anadyr'skiy districts of Chukotka Autonomous Okrug. According to the population census of 2010, the Evens live compactly in the Republic of Sakha (Yakutia) - 11 675, in Magadan Oblast' - 2527, in Kamchatka Krai 1779, in Khabarovsk Krai - 1272, in Chukotka Autonomous Okrug - 1407. 6080 people are the Even native-speakers among them. The
Evens population dynamics according to the censuses is the following: in 1959-9 121 people, in 1970-12 029, in 1979-12 523, in 1989-17 199 and in 2010-18660.

Since 1940s the socio and economic environment has been changing (the influx of Russians, tendency for growing size of households, Evens' migration from the places of their original residence, decline of mother tongue education in schools) and the assimilation of the Evens by the Russian population takes place. In Yakutia, this process has been accomplished by a fastpaced shifting of the Evens to use of the Yakut language in everyday and formal communication. The process of the Russian language learning has resulted in the fact that the Evens started to forget their mother tongue: in 1959 the language was considered as a native one for $77.5 \%$ of the Evens, in 1989 - only for $43.8 \%$. The Evens were still being assimilated by the Yakut population: in 1979, $44 \%$ of the Evens spoke the Even language as the mother tongue, while in 1989-35\%.

The population census of the Russian Federation in 2010 indicates that $89.6 \%$ of the Evens can fluently speak the Russian language, while only $21 \%$ speak the Even one.

Just after 1980s, there were active steps in the language policy taken to revive the Even language and culture. An essential role in the process was mainly played by the Evens representatives, e. g., V.A. Robbek, V. G. Belolyubskaya, A. V. Krivoshapkin, E. N. Bokova, Kh. I. Dutkin, R. S. Nikitina, A. A. Alekseev, U. V. Kanyukova, V.S. Bargachan-Keymetinov, O. N. Keymetinova, N. A. Zybin, M. N. Tarasova (Adukanova), S. I. Sharina (Struchkova) and others.

\section{Researches Review}

The first written sources of the Even words were presented in «North and East Tartary» by Nicolaes Witsen, a Dutch explorer and diplomat (Amsterdam, 1692). In the $18^{\text {th }}$ century, the Even language data and materials were collected by D. G. Messerschmidt, Ph. J. Strahlenberg, P. S. Pallas, J. I. Lindenau and others.

\section{The Even Language Studies in the $19^{\text {th }}$ Century}

The pioneer attempts to create the writing form of the Even language are dated as 1840s and 
are connected with the Even translation of Gospel initiated by the Russian Orthodox Church. The translation was made by Stephan Popov, a Russian evangelist and arch-priest of the city of Okhotsk, and published in Kazan' in 1880. Apart from that, Popov created the Even ABC-book («Tungus ABC-book», the Synod Publishing House, Moscow, 1858) and complied a concise Even-Russian dictionary (about 1300 words) that was published in 1859 and 1900 (Gortsevskaya, 1959: 16).

\section{The Even Language Studies in the Soviet Era (the 20 ${ }^{\text {th }}$ Century)}

V. G. Tan-Bogoraz made immense contribution to the Even language studies. His works are comprehensive and useful enough since, in fact, he was a pioneer in the Even and paleoAsiatic studies in the Soviet Russia. Thanks to Tan-Bogoraz the first information about the Even grammar, lexis and phonetics, as well as the original texts and folklore and ethnographic materials was published (Bogoraz, 1931). He was directly engaged in the process of establishing the Institute of the Peoples of the North named after P. G. Smirdovich at the All-Russia Central Executive Committee of USSR (VTSIK), which further work on creating the writing system for the small-numbered indigenous peoples of the North, Siberia and the Far East, and imprinted his name in the history of linguistics. The scientific active collaboration of the Institute's students and teachers in 1930-1941 did much on creating alphabets, ABC-books, textbooks, dictionaries and research articles on the languages of the peoples of the North.

The Even language was studied by V.G. Bogoraz, V. I. Levin, V. I. Tsintsius, L. D. Rishes, N. P. Tkachik, K. A. Novikova, N. I. Gladkova, V. I. Lebedev, N. A. Zybin, B. L. Krongauz, Kh. I. Dutkin, A. A. Danilova, V. A. Robbek. In 1931 the $1^{\text {st }}$ Tungus Collection included «The Materials on the Lamut Language» by V. G. Bogoraz-Tan.

V. I. Levin collected and published «The Concise Even-Russian Dictionary» (Leningrad, Uchpedgiz, 1936) and «The Even Self-Study Book» (Moscow-Leningrad, 1935). V. I. Tsintsius published «The Even (Lamut) Grammar Outlines. Part 1» in 1947 (Leningrad, Uchped- giz, 1947). In 1948 K. A. Novikova defended Ph.D. dissertation on «Ol'skiy Dialect of the Even Language». L. D. Rishes published «The Russian-Even Dictionary» (Leningrad, Uchpedgiz, 1950). The Proceedings of the Yakut Section of the USSR Academy of Sciences, Siberian Branch, include two of her works - «Some Data on the Western Dialect of the Even Language» (Yakutsk, 1955) and «The Basic Features of the Even Dialects of Momskiy District, Yakutia Autonomous Soviet Socialistic Republic» (Yakutsk, 1958). V. D. Lebedev defended his PhD dissertation on «The Momskiy Dialect of the Even Language» at the Institute of Language Studies of the USSR Academy of Sciences (Leningrad Branch) in 1970.

\section{Post-Soviet Period (1991-2000)}

«Prosvescheniye Leningrad Division» Publishing House issued in 1991 a textbook called «The Even Language» by K. A. Novikova, N. I. Gladkova and V. A. Robbek, written for the colleges of education. Kh. I. Dutkin published a monograph «The Allaikh Dialect of the Yakut Even» (Saint-Petersburg, Nauka, 1995) based on his former $\mathrm{PhD}$ dissertation. Within the same period, he published other works in Yakutsk - «The Concise Phrase-Book for the Even Language Learners» (1992), «Табаһыттарга эбээннии-сахалыы тылдьыт» («The Even-Yakut Dictionary for Reindeer Breeders», 1992), «The Even Language: Status and Research Problems»» (1993). A. A. Danilova carried out a research on «The Everyday Lexis of the Even Language» (Yakutsk, The Language, Literature and History Institute, 1991).

A. A. Petrov published his research papers «The Lexis of Arts and Crafts of the Evens» (in «The Problems of the Languages of the North» dedicated to the $79^{\text {th }}$ anniversary of Associate Professor N. I. Gladkova, Yakutsk, 1991), «The Lexis of Spiritual Culture of the Evens (Folk Arts and Ceremonies)» (Leningrad, 1991), «The Lexis of Traditional Dance of the Evens» (in «Language - Myth - Culture of the Peoples of Siberia», Yakutsk, 1991), "The Even Language» (in «The Red Book of the Languages of the Peoples of Russia. Encyclopedic Reference Dictionary», Moscow, Academia, 1994), «Text Ethnolinguistics (the Evens' Ceremonies Lex- 
is)» (Pyatigorsk, 1995), «The Lexis of Religious Worldviews of the Evens» (in «The Issues of Even Philology and Ethnology», Yakutsk, The Institute of the Problems of the Small-numbered Peoples of the North, Russian Academy of Sciences, Siberian Branch, 1997).

V.A. Robbek authored a monograph on the Even morphology called «Grammar Categories of the Even Verb» (Saint-Petersburg, Nauka, 1992). In the same year (1992) he had the defence of the doctoral dissertation in Saint-Petersburg («Grammar Categories of the Even Verb through Functional and Semantic Aspects»). In 1997 and 1999 «The Even-Russian and Russian-Even Dictionary» by V. A. Robbek, Kh. I. Dutkin and A. A. Burykin was re-published in SaintPetersburg («Prosveshchenie» Publishing House). E. V. Robbek wrote the scientific paper «The Reflection of the Bear-Cult in the Even Language of Beryozovka» and published it in the collection of articles «Problems of the Even Philology and Ethnology» (Yakutsk, 1996); in 1993 he compiled «The Even-Russian Phrase-Book» together with N.P. Tarabukin.

V. G. Belolyubskaya defended the PhD dissertation in 1997 (Saint-Petersburg) on the topic «Syntactic Words of the Even Language». A. A. Burykin conducted a problematic research on «The Written and Oral Forms of the Even Language: The Dialect Structure and Functional Status of Dialects» and published its results in the book «Small-numbered Peoples of the North, Siberia and the Far East. The Problems of Language Preservation and Development» (Saint-Petersburg, 1997). S. I. Sharina released her monograph on «The Category of Quantity in the Even Language» (Saint-Petersburg, SaintPetersburg University Publishing House, 1999). A. L. Malchukov also published his monograph «The Syntax of Simple Sentence in the Even Language. Structural and Semantic Aspects»» (Saint-Petersburg, Nauka, 1999), as well as his articles on «Distributive Construtions and Verbal Valence in Even» (in «Languages of the World, Munich, 1992) and «The Syntax and Semantics of the Adversative Constructions in Even» (in «Genko Kenkyu», 1993), «Even» (Unterschleissheim \& Newcastle, Lincom Europa, 1995), «Ethno and Socio-linguistic Features of the Evens of Tomponskiy District of Yakutia» (in «The Small-numbered Peoples of the North, Siberia and the Far East. The Problems of Languages' Preservation and Development» (SaintPetersburg, 1997); «Russian-Even Grammar Interference» (in «The Issues of Even Philology and Enthlogy», Yakutsk, 1997; «Russian-Even Language Relations» (in «Contactology Encyclopedic Reference Dictionary», Moscow, 1994, with A. A. Petrov as a co-author).

\section{The Even Language Studies in the $21^{\text {st }}$ Century}

S. I. Sharina published her monograph on «Personality and Possessiveness in the Even Language» (Novosibirsk, Nauka, 2001) and together with R.P. Kuz'mina complied «The RussianEven Phrase-Book» (Yakutsk, The Institute of Humanitarian Studies and the Problems of the Small-numbered Peoples of the North, Russian Academy of Sciences, Siberian Branch, 2014), which includes a short grammar reference and topical vocabulary.

In 2002, in the Institute of Language Studies, Russian Academy of Sciences, A.L. Mal'chukov defended his doctoral dissertation «The Even Syntax: Structural, Semantic, Communication Aspects» and in 2008 he transformed it into a significant monograph. In 2003, V. A. Robbek, M. E. Robbek, N. P. Tarabukin, E. V. Robbek became the authors of «The Even-Russian and Russian-Even Dictionary with the Even-Russian Phrasebook for Nomadic Schools» (SaintPetersburg). In the same year a monograph by G. Belolyubskaya (Arkuk) called «The Even Language: Particles. Postpositions. Conjunctions») was also published in Saint-Petersburg.

M.S. Tolstova (Belolyubskaya) published her article dealing with the folk knowledge of the Evens "The Lexis Related to the Evens" Metrology» (in «The Northern Studies», SaintPetersburg, Herzen State Pedagogical University, 2004) which introduced new facts in such poorlyexplored sphere of the Even lexis. In the same year she published the article «The Lexis of the Evens' Medicine» based on the materials of the scientific conference (Saint-Petersburg, 2004).

A. A. Burykin wrote a book «The Written Language of Small-numbered People (Evens)» in 2004 under the project of the Department for Peoples and Federate Interaction of the Repub- 
lic of Sakha (Yakutia) in Saint-Petersburg and published it in «Peterburgskoye Vostokovedeniye (Saint-Petersburg Oriental Studies)» Publishing House. The author revealed some key theses of his doctoral study and summarized his years-long observations over the Even language.

A. L. Malchukov and V. S. Elrika coauthored and published their article with the research of the issues of Even syntax (in «The Northern Studies at Higher Educational Institution. The Issues of Researching and Teaching. The Herzen Readings Materials», SaintPetersburg, Herzen State Pedagogical University, 2001). A. L. Malchukov devoted his article to the reciprocity in the Even language («Reciprocal Construction in Even», in «Typology of Reciprocal Constructions, Amsterdam, Benjamins, 2007, edited by V.P. Nedjalkov).

«Ofset» Publishing House released «The Guide for Nomadic Schools Teachers» and «The Even-Russian Dictionary for Nomadic Schools» prepared by V. A. Robbek, M. E. Robbek, S. N. Savvinova and other (Yakutsk, 2006). V.A. Robbek was the first who developed the theory of Even morphology in the context the theory of functional grammar in «Grammar Categories of the Even Verb: Functional and Semantic Aspect» (in «The Monuments of Ethnic Culture of the Indigenous Small-numbered Peoples of the North, Siberia and the Far East», Novosibirsk, Nauka, 2007, volume 11 of the Series «Monuments of the Ethnic Culture of Indigenous Smallnumbered Peoples of the North, Siberia and the Far East»). In 2008, in the journal of the Altai studies «Altai Hakpo» (Seoul) G. V. Robbek and E. V. Nesterova published «The Yakut, Even and Tungusic Correlations» and «Sound-Imitative Words in the Even Language» respectively. R.P. Kuz'mina defended her PhD dissertation on «The Lakhmunkh Dialect of the Even Language» (Saint-Petersburg, 2008).

Kh. I. Dutkin and M. Kh. Belyanskaya prepared a monograph on «The Tundra Dialect of the Western Language of Even. Ethnolinguistic and Ethnogeographic Study» (Saint-Petersburg, 2009). Thanks to the recent $\mathrm{PhD}$ dissertations defences by E. V. Nesterova and G. V. Robbek, the Even lexis layers of imagery and physical culture have been studied. M.E. Robbek published in Yakutsk and Novosibirsk lexicographically informative and illustrative works on clothes decoration, weaves and designs in the folk crafts and on the Evens' traditional cuisine. E. E. Balaganchik, A. D. Slepnyova compiled and published their «Illustrative Dictionary of the Even Language» and V.A. Robbek and M.E. Robbek «The Even-Russian Dictionary» (for almost 5500 words). Both are the guides for elementary school children (Saint-Petersburg, «Prosveshchenie» Publishing House Division).

In «Duma» Publishing House «The Concise Even-Russian Dictionary» by V. I. Levin was re-published and fitted with colored images and three supplements in 2006 in Saint-Petersburg (edited by U. V. Kanyukova and consulted by M.S. Tolstova). It is also worth to mention a fundamental «The Even-Russian Dictionary» compiled by V. A. Robbek and M. E. Robbek in «Monuments of the Ethnic Culture of Indigenous Small-numbered Peoples of the North, Siberia and the Far East» Series (Novosibirsk, 2005). The first part of «The Even-Russian Dictionary: Interpretation and Etymology» by V. Af. Keymetinov was published in 2005 (Yakutsk, «Ofset») and was fitted with other volumes.

In the Research Institute of National Schools of the Republic of Sakha (Yakutia) U.P. Tarabukina created a topical dictionary called «The ABC-Book of Politeness» («The Even ABC-Book of Politeness», Yakutsk, 2008). E. V. Beglova published her article on «Taboos in the Even Language» in «The Languages and Spiritual Culture of the Peoples of Circumpolar Arctic» (Saint-Petersburg, 2008). V. S. Fedorenkova (Yermolayeva) wrote an article «On the Problem of Aspect and Temporal Forms of the Even Verb (based on the Lamunkh dialect material), in which she studied the attributive concords in Even dialects. The paper was published in the journal «Problems of History and Culture of North Countries and Territories» (No. 2, 2010) dedicated to the $80^{\text {th }}$ anniversary of the Institute of the Peoples of the North at Herzen State Pedagogical University.

At present, the problem of the Even language and its folklore is studied by A. L. Mal'chukov, A. A. Burykin, V. G. Belolyubskaya, S. I. Sharina, A. A. Petrov, G. V. Robbek, E. V. Nesterova, R. P. Kuz'mina, S. N. Savvinova, I. I. Sadovnikova, V.A. Keymetinov, V.S. Fedorenkova 
(Yermolayeva), E. E. Beglova (Balaganchik), M.S. Tolstova (Belolyubskaya) and others. More information on the history of Tungusic studies can be found in the monograph by A. A. Petrov (Petrov, 2019).

\section{The Even Language Teaching}

In the Russian Federation the teaching of the Even language at schools is concentrated mainly in Far Eastern Federal Okrug: in the Republic of Sakha (Yakutia), in Magadan Oblast', Kamchatka and Khabarovsk Krai and Chukotka Autonomous Okrug. It should be noted that in the Republic of Sakha (Yakutia) the Even language (along with Evenk, Dolgan, Yukagir and Chukchi) is recognized according to the law as the official language in the areas of compact ethnic residence.

The language is taught in preschool educational institutions and at schools of the Republic of Sakha (Yakutia), Kamchatka and Khabarovsk Krai, Magadan Oblast' and Chukotka Autonomous Okrug. For example, there are 7 children studying in the preschool subdivision of the municipal state-owed educational institution «Ayankinskaya Secondary School» in Ayanka, Penzhinskiy District (the teacher - K. M. Delyanskaya); in the municipal budgetary preschool educational institution «Kindergarten of combined type 'Rodnichok'», in Anavgay, Bystrinsky District (all groups, 42 children, the teacher G. I. Kizyavka).

In the state budgetary educational institution «Experimental boarding school 'Arktika'» 32 Evens were enrolled in the 2017-2018 academic year. The teacher of the Even language N. M. Ochirova together with her students prepared new educational videos with the Even songs, poems and dialogues. The teacher participated in a competition held in November 2017 by the Federal Institute for the Development of Education and won the $1^{\text {st }}$ prize. In Srednekolymsky Ulus of the Republic of Sakha (Yakutia), the Even language is taught at Berezovskaya secondary school named after V. A. Robbek (the teacher and methodologist of the native language is U.P. Tarabukin). The classes are held at this school for 3 hours a week, as well as there is extra curriculum time under the project «Ethnopark 'The World of the Even'». The language is also taught in Tom- ponsky Ulus (Topolinoe settlement), Ust-Yansky Ulus (the teacher - E. E. Lebedev), Momskiy Ulus (Sasyr settlement - Ulakhan Chistay) and in Allaikhovsky ulus. In Magadan Oblast' the Even language is taught in Omsukchan District in Omsukchan settlement (18 students); in SeveroEvensky District in the following settlements Garmanda (8 people), Gizhiga (11 students), Evensk (19 students), Takhtoyamsk (16 students) and Seimchan (at the centre of additional education for children, 7 students). According to the assistant professor of the Department of Native Languages, Culture and Life of the Indigenous Peoples of the North at the Regional State Autonomous Institution of Additional Vocational Education «Kamchatka Institute for the Development of Education» V.R. Dedyk, the Even language was taught in 2018 at the following schools in Kamchatka: the municipal state-owed educational institution «Ayanka Secondary School», Penzhinsky District (grades 5-9, elective course, 14 students, the teacher - K. V. Delyanskaya); in the municipal budgetary educational institution «Anavgai Secondary School» in Anavgai, Bystrinsky District (grades 1-9, compulsory, 62 students, 1 hour a week, the teacher - M.N. Tarasova). The authors of textbooks, dictionaries and manuals are V. I. Tsintsius, L. D. Rishes, V. A. Robbek, K. A. Novikova, N. I. Gladkova, H. I. Dutkin, A. V. Krivoshapkin, R. S. Nikitina, U.P. Tarabukina and others.

As for pedagogical colleges the Even language was taught (the teacher - V. G. Belolyubskaya) in Yakut Pedagogical College No 1 until 1991 (before the Department of Northern Philology at Yakut State University named after M. K. Ammosov - now North-Eastern Federal University in Yakutsk - was opened); in Anadyr Pedagogical College (the teacher-O. N. Ninbit).

As for the universities, the language was taught in the Institute of the Peoples of the North named after P. G. Smidovich from 1930 to 1941; at the Department of the Peoples of the Far North, Herzen Leningrad State Pedagogical Institute - now the Institute of the Peoples of the North of Herzen State Pedagogical University of Russia - from 1953 till the present time. The Even language was taught in different years by V. G. Bogoraz-Tan, V. I. Tsintsius, V. I. Levin, N. I. Gladkova, B. L. Krongauz, A. A. Burykin, 
N. A. Zybin, A. A. Petrov, V.S. Elrika, E. E. Beglova (Balaganchik), M. S. Tolstova (Belolyubskaya), V.S. Fedorenkova (Ermolaeva). Since 1991 (when the Department of Northern Philology at Yakut State University was founded) to the present time in Yakutsk the Even language has been taught by V. A. Robbek, H. I. Dutkin, V. G. Belolyubskaya, S. I. Sharina, A. A. Vinokurova, E. A. Krivoshapkina.

\section{Ethnolinguistics. The Problems of the Even Language Ethnolinguistic Ecology}

For the first time the problem of ethnolinguistic ecology of the small-numbered peoples of Russia was stated in 1994 by the Director of the Institute of Languages of the Peoples of Russia, Academician of the Russian Academy of Natural Sciences, Doctor of Philology, Professor V.P. Neroznak in his introductory article to the first edition of the «Red Book of the Languages of the Peoples of Russia» (Neroznak, 1994: 5-9). As a scientific sphere, the ecology of culture was initiated through the works of the Academician D. S. Likhachev (Likhachev, 1979).

The vectors of ethnolinguistic ecology are determined by the necessity to preserve endangered languages. The following main vectors should be noted:

1) Scientific research. It is necessary to welcome both fundamental and applied research of the Even language concerning its various levels: sound (phonology), vocabulary (lexis), changes in various forms of the word (morphology); different patterns of phrases and sentences (syntax). The separate area of research should be the semantic aspect of linguistic phenomena (semantics). In this vector of ethnolinguistic ecology the teams of academic research institutions make a significant contribution to and should work on systemic fundamental research: the Institute of Language Studies of the Russian Academy of Sciences, the Institute of Linguistic Research of the Russian Academy of Sciences, the Institute of Philology of the Russian Academy of Sciences (Siberian Branch), the Institute of Humanities and Problems of Indigenous Peoples of the North of the Russian Academy of Sciences (Siberian Branch) and others. The contribution of practical scholars from the leading scientific and educational centres of Russia, such as the Institute of
Peoples of the North of Herzen State Pedagogical University (Saint-Petersburg), North-Eastern Federal University named after M.K. Ammosov (Yakutsk), Buryat State University named after Dorzhi Banzarov (Ulan-Ude), Yakutsk Research Institute of National Schools and others is invaluable in applied researches. It is necessary to take into consideration a great contribution to the study of the Even language and the experience of a large group of school, teacher training colleges and universities teachers. The researches should be carried out primarily in those regions where the centres of the native language and culture do still remain (where traditional householding is being practiced: reindeer herding, hunting, fishing, gathering).

2) Teaching. Recently, in addition to the existing education system, i. e., in stationary preschool educational institutions, schools, colleges and universities, the teaching the native language in the family and in nomadic schools (in conditions of migrations in taiga and tundra areas) has become widespread. In this context an active use of modern teaching tools should be highlighted. Paper textbooks, dictionaries, manuals, language labs have been replaced by the Internet and modern electronic teaching materials. For example, in the Even language teaching, such textbooks as «Grammar of the Even language» (electronic textbook by A. A. Burykin, S. I. Sharina) are successfully used; E. E. Beglova (Balaganchik) created «The Illustrated Dictionary of the Even Language: A Multimedia Manual for 1-4 Grades of General Education Institutions» and «The Electronic Morphological Dictionary of the Even Language»; the same experience is gained for the Negidal language: A. V. Kazarova, D. I. Nadeina, D. M. Bereltueva introduced an electronic phonetic textbook on the Negida language «Negida Hesenin» (Khabarovsk, 2009) for preschool, primary school and university. One of the important tasks for the authors is the use of these manuals for the language and national culture studies in teaching the native language. There are such sections presented in the manuals: «Initial stage of language training»; «ABC-book with alphabet, fairy tales, texts and games», «Improving language practice at two levels», «Vocabulary», «Phrasebook», «Supplementary multimedia materials». 
A growing interest in the game forms of learning through visualization is observed: the mother tongue in tables, topical dictionaries and alphabets. The most vivid examples are the following: «Happy Even Alphabet» by A. A. Burykin (Saint-Petersburg, Drofa, 2002); «Denturdi ABC-Book» («The Even Alphabet in Verse»), «Textbook for Primary School Students» (St. Petersburg, «Prosveshchenie» Publishing House Division, 2003), «Entertaining Grammar of the Even language: A Textbook for 1-4 Grades Students of Educational Institutions» (SaintPetersburg, «Prosveshchenie» Publishing House, Saint-Petersburg Division, 2007) by U.P. Tarabukina and others.

M. N. Tarasova (Adukanova), R. S. Nikitina, U.P. Tarabukina and other practicing teachers have developed and introduced into the educational process a new type of classes called «The Lessons of Ancestors». Methodological developments for teachers of the native (Even) language according to this methodology allow to familiarize students with the basics of their material and spiritual culture. Recently, in school and university teaching, the method of ethnolinguistic education has been applied. Its essence lies in the use of insights in the language through ethnolinguistic traditions when learning the mother language and culture.

3) Ethnolinguistics. As a branch of linguistics, ethnolinguistics (EL) studies language in the relation with the folk culture (Tolstoy, 1995). It has established its position and received international recognition quite long ago. Apart from the Russian scientists, linguistic scientists from different countries, e. g., the USA, France, Poland, as well as the CIS countries (Kazakhstan, Kyrgyzstan, etc.), are successfully working in this area. We can find various definitions of EL as a scientific section of modern linguistics in dictionaries, textbooks, monographic studies (see the works by N. I. Tolstoy, N. A. Kondrashov, A. M. Kuznetsov, A. S. Gerd, E. V. Perekhvalskaya and others) (Petrov, 2013: 23-25). The EL of the indigenous small-numbered peoples of the North of Russia (including the Tungusspeaking peoples) was developed by the scientific works of linguists and ethnographers, such as V. G. Bogoraz, L. Ya. Shternberg,
V. I. Iokhelson, G. M. Vasilevich, V. I. Tsintsius, V.D. Lebedev and others.

The EL studies the language in close connection with the material and spiritual culture of the ethnos. In many respects, the study of languages (including Even) is facilitated by students' participation in folk song and dance groups at schools and universities. There is the student folklore and choreographic ensemble (now the theatre studio) «Northern Lights» (the founder - T.F. Petrova-Bytova, the Honoured Worker of Culture of the RSFSR) at Herzen State Pedagogical University. Performance and acquaintance with the folk songs, dances, national musical instruments (drum, mouth harp, etc.) expands the students' vocabulary. The ensemble has performed a lot at the venues and concert halls of Leningrad and Saint-Petersburg, in the cities of Russia, Baltic States and abroad (France, Norway, England, Finland, etc.), promoting the traditional and modern art of the indigenous peoples of the North, Siberia and the Far East of the Russian Federation.

An important factor in the study of the Even language by the students of the North is their involvement in creative workshops on decorative and applied arts, e. g., the practice of the Institute of Peoples of the North. The students can embroider with beads, carve items from birch bark and wood, make art objects from mammoth tusks and ivory at the abovementioned Institute. At the same time, they learn nomination and semantics of the patterns and ornaments, names of raw materials (leather, suede, fur, etc.), tools and objects of traditional and modern art and compose thematic dictionaries and glossaries.

In the course of lectures and practical classes the students get acquainted with the vocabulary of the native culture: the life cycle rituals (birth, wedding, funeral) and rites of passage (hunting, fishing, bear cult, etc.); religions (animism, totemism, shamanism, Christianity); folk knowledge (metrology, meteorology, cosmology, geography, medicine, folk cuisine, taboos, folk songs and dances, ritual poetry, minor genres of folklore: riddles, proverbs, sayings; traditional etiquette, folk calendar, colour coding system at different levels of language, orientation in space and worldview, etc.). 
At the same time some researchers express an opposite point of view. For example, during «Languages and Cultures of the Indigenous Peoples of the North, Siberia and the Far East: A Vector of Preservation and Development» discussion within the $8^{\text {th }}$ International Forum «Arctic: The Present and Future» on December $7^{\text {th }} 2018$ at the Institute of the Peoples of the North, V.S. Kharitonov and his followers in social networks (the project «The Country of Languages») expressed the opinion that the ethnolinguistic method is effective only for 1-7 grade students inclusively, so it does not work for the older age groups.

The recording of oral form and creating of an audiovisual fund of the native language (regardless of jargons or dialects) are of great relevance for the Even language preservation, study and teaching. In this context we can name the following colleagues - G.I. and A.N. Varlamovs (Yakutsk), N. Ya. Bulatova, O.N. Morozova, G. A. Struchkov (Blagoveshchensk) - who successfully work in the field of the Even language, and D. M. Bereltueva, A. V. Kazarova, D. I. Nadeina (Khabarovsk) - who work in the field of the Negidal language.

Due to the native language and traditional culture vanishing, such components of ethnolinguistic ecology as scientific research of surviving centres of spoken native language and culture (mainly, in the places of compact residence and traditional types of householding - reindeer breeding, hunting, fishing, gathering), and also teaching these languages at all levels of education system (family, preschool educational institutions, primary and secondary schools, secondary specialized educational institutions and universities) become particularly relevant. Currently, it is especially important to apply the research results of such interesting area of linguistics as ethnolinguistics.

\section{Conclusion}

In Russia, fundamental and applied researches of the Northern group of Tungusic languages, including Even, have been carried out for more than three centuries. Scientists of different generations have made a huge contribution to the formation and development of scientific studies in different sections of the Even language (pho- netics, vocabulary, morphology, syntax), and also created unique scientific schools of V. G. Bogoraz, V. I. Tsintsius, V. A. Robbeck. Among the representatives of the indigenous small peoples of the North, Siberia and the Far East, the scientific and creative intelligentsia of the Even language folklore and literature researchers included N. S. Tarabukin, P. A. Stepanov-Lamutsky, V. D. Lebedev, V. A. Robbek, V. G. Belolyubskaya, A. V. Krivoshapkin, M. N. Amamich, V.S. Keimetinov-Bargachan, R. S. Nikitina, U.P. Tarabukina, U.V. Kanyukova, N. A. Zybin, A. I. Hardani, V. S. Elrik, S. I. Sharin, I. I. Sadovnikova, E. V. Nesterova, R. P. Kuz'mina, S. N. Savvinova, V. S. Fedorenkova, E.E. Beglova (Balaganchik), M. S. Tolstova (Belolyubskaya) and others. An invaluable role in this process was played by the Institute of the Peoples of the North, founded in Leningrad in 1930, the traditions of which are being continued today by the Institute of Peoples of the North at Herzen State Pedagogical University of Russia. At present, the study of the Even language is concentrated in scientific and educational centers in SaintPetersburg, Moscow, Novosibirsk, Yakutsk.

When teaching the native Even language, the method of ethnolinguistic education is successfully applied - it provides an insight in the vocabulary and semantics of the language through the connection between the language and the national spiritual and material culture. New forms of classes are being introduced (for example, the lessons of ancestors), and teaching tools, dictionaries, electronic textbooks are being developed for the students of nomadic schools.

On the basis of the Law on the Languages of the Peoples of the Russian Federation (as amended by Federal Laws of July $24^{\text {th }} 1998$, No $126-\mathrm{FL}$, of December $11^{\text {th }} 2002$, No 165-FL), the laws on languages were adopted in the constituent entities of the Russian Federation (in the Republic of Sakha (Yakutia), Chukotka Autonomous Okrug and others), which guarantee the rights of the indigenous small-numbered people - the Evens - to use their mother tongue in different spheres of the national economy, their protection, revival and development. This contributes to the tasks and fulfillment of the basic requirements of ethnolinguistic ecology. A public organization, the Association of Indigenous Peoples of the 
North, Siberia and the Far East of the Russian Federation, which has its branches in almost all regions where the Evens live, is also making huge efforts to implement these provisions.

The current Concept of Sustainable Development of Indigenous Peoples of the North, Siberia and the Far East of the Russian Federation (Decree of the Government of the Russian Federation No. 132-p dated February $4^{\text {th }} 2009$, signed by V. V. Putin) also identified the issues of preserving and developing the native languages of these peoples.

On July $28^{\text {th }} 2017$, by the Order of the President of the Russian Federation V. V. Putin, who supported the initiative of the Association of Indigenous Small-Numbered Peoples of the North, Siberia and the Far East of the Russian Federation, a Charitable Support Foundation was created.

Thus, many participants are involved in the implementation of the ethnolinguistic ecology foundations, i. e. the state bodies and public organizations, scientists, writers, families, preschool educational institutions, school teachers and university faculties, tutors, artists, craftsmen and other interested parties.

Particular attention should be paid to the aspect of the Even ethnotexts translation. In this case translation could be considered as an effec- tive tool in each of the abovementioned areas of the Even language functioning - language and culture research, teaching and ethnolinguistic studies. The ethnotexts translation provides the valuable information for the scholars working in various areas of the Even language comprehension. The project activity in all these main areas could be applied on various issues of a «life» of any unique language of smallnumbered indigenous peoples of the today's multilingual and polycultural world (Koptseva, Razumovskaya, 2020). Following the current trends in translation studies as a part of the humanities, the translation can be treated as the tool of research and desired revival of the endangered languages. It is also important to state that the ethnotexts translation can also result into the emergence of ethnotranslation studies as a branch of diversified translation studies.

The United Nations General Assembly adopted a resolution proclaiming the year of 2019 as the International Year of Indigenous Languages. There is a hope that with our efforts we will be able to preserve the unique cultural heritage - the languages of indigenous peoples of the North, Siberia and the Far East. Among them, the unique language of the Evens - the natives of Northeast Asia-occupies a worthy place.

\section{References}

Bogoraz, V.G. (1931). Materialy po lamutskomu yazyku [Materials on the Lamut language]. In Tungusskiy sbornik [Tungus Collection], 1, 71-106.

Gortsevskaya, V.A. (1959). Ocherk istorii izucheniya tunguso-man'chzhurskih yazykov [Essay on the History of the Tungus-Manchu Languages Study], Leningrad, Uchpedgiz.

Koptseva, N.P., Razumovskaya, V.A. (2020). [The New Projects of the Evenk Language Revival]. In Yazyk Severa: Materialy Vserossiyskoy Nauchnoy Conferencii [A Language of the North: Materials of the All-Russia Scientific Conference], Saint-Petersburg, Politicheskaya Encyclopedia, 36-44.

Likhachev, D.S. (1979). Ekologiya kul'tury [Ecology of Culture], Moscow.

Neroznak, V.P. (1994). Malochislennye narody Rossii: problemy etnolingvoekologii [Small-numbered Peoples of Russia: Problems of Ethnolinguaecology]. In Krasnaya kniga yazykov narodov Rossii. Enciklopedicheskiy slovar'-spravochnik [The Red Book of Languages of the Peoples of Russia. Encyclopaedic Dictionary with Reference], Moscow, Academia.

Petrov, A.A. (2013). Leksika duhovnoj kul'tury tungusoyazychnyh narodov (evenki, eveny, negidal'cy, solony) [The Vocabulary of the Spiritual Culture of the Tungus-Speaking Peoples (Evenks, Evens, Negidal, Solons)], Novosibirsk, Nauka.

Petrov, A.A. (2019). Istoriya izucheniya tunguso-man'chzhurskih yazykov v Rossii (ocherki i issledovaniya) [The History of the Tungus-Manchu Languages Study in Russia (Essays and Researches)], SaintPetersburg, Almaz-Graf. 
Rasporyazhenie Pravitel'stva $R F$ «Ob utverzhdenii perechnya korennyh malochislennyh narodov Severa, Sibiri i Dal'nego Vostoka Rossijskoj Federatsii» ot 17 Aprelya 2006 g. № 536-r (s izmeneniyami Postanovleniem Pravitel'stva RF ot 26 Dekabrya 2011 g.) [Decree of the Government of the Russian Federation «On Approval of the List of Indigenous Small-numbered Peoples of the North, Siberia and the Far East of the Russian Federation» dated April 17, 2006 No. 536-p (as amended by the Resolution of the Government of the Russian Federation of December 26, 2011)].

Tolstoy, N.I. (1995). Yazyk i narodnaya kul'tura. Ocherki po slavyanskoy mifologii i etnolingvistike [Language and Folk Culture. Essays on Slavic Mythology and Ethnolinguistics], Moscow, Indrik. 